
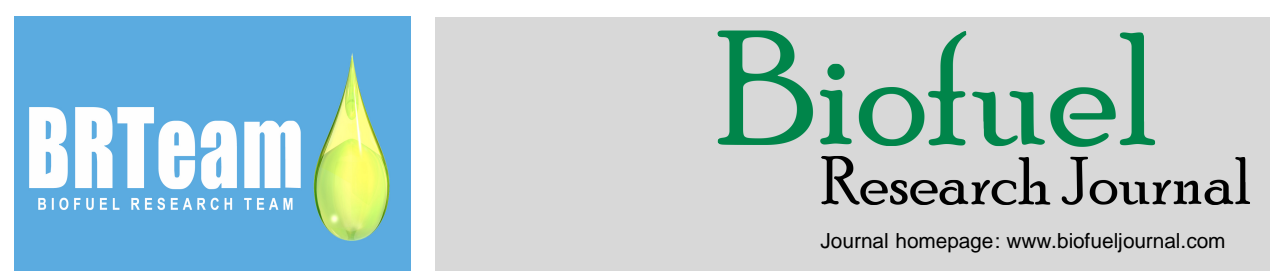

Journal homepage: www.biofueljournal.com

Review Paper

\title{
A comprehensive review on the implementation of the biorefinery concept in biodiesel production plants
}

\author{
Christian David Botero Gutiérrez, Daissy Lorena Restrepo Serna, Carlos Ariel Cardona Alzate *
}

Instituto de Biotecnología y Agroindustria, Departamento de Ingeniería Química, Universidad Nacional de Colombia sede Manizales, Km. 7 vía al

Magdalena, Manizales, Colombia.

$>$ Integral use of biomass under biorefinery concept in general leads to economic, environmental, and social advantages over individual processes.

$>$ Biorefineries must be conceptualized beforehand in order to achieve optimal selection of technologies, raw materials, and products.

$>$ Sole production of biodiesel on the analyzed scale would not cover all the production costs.

$>$ Multiple-products production such as xylitol, ethanol, syngas, and electricity in addition to biodiesel would enhance the overall viability of the plant.

\section{HIGHLIGHTS}

\section{GRAPHICAL ABSTRACT}

\section{ARTICLE INFO}

\section{Article history:}

Received 23 June 2017

Received in revised form 25 August 2017

Accepted 25 August 2017

Available online 1 September 2017

\section{Keywords:}

Biorefinery

Conceptual design

Biodiesel

Economic viability

Environmental sustainability

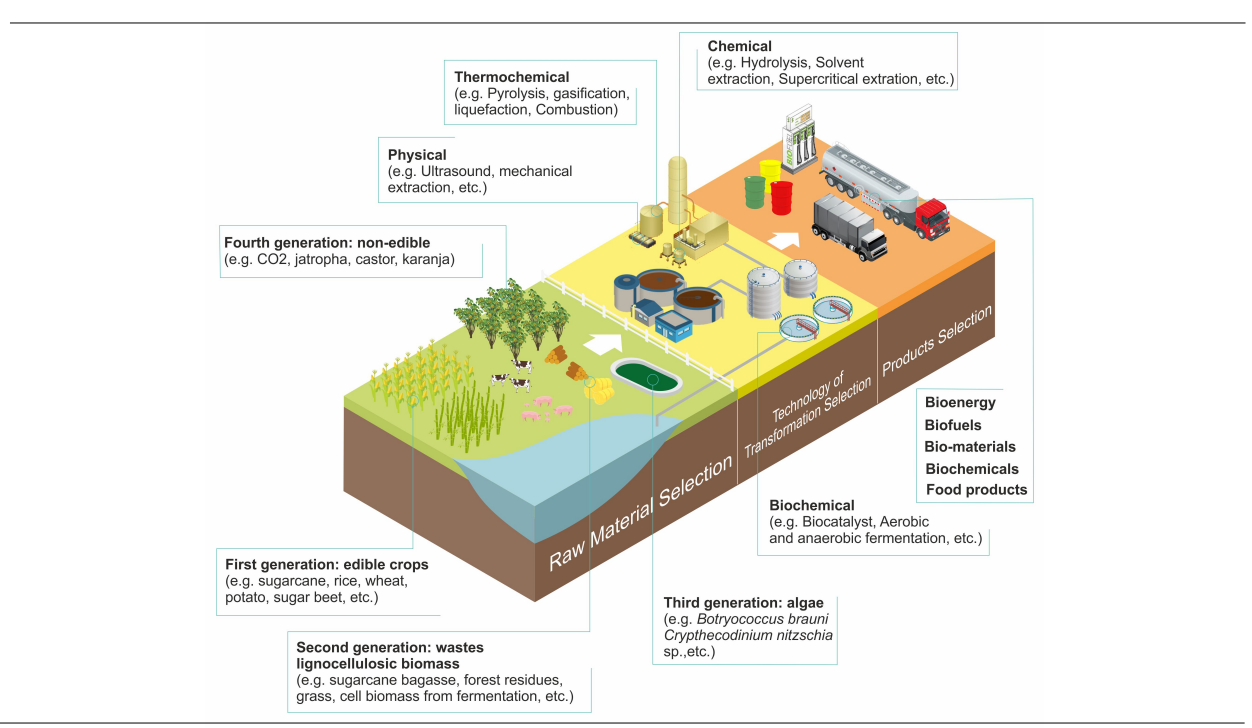

\section{ABSTRACT}

Biodiesel is a promising alternative to petroleum diesel and its production from various generations of feedstocks by using different technologies has been constantly growing globally. However, in spite of such large scale of production, serious considerations should be taken into account to ensure the long-term sustainability of biodiesel production. This issue becomes more of concern given the fact that some generations of feedstocks used for biodiesel production are in clear conflict with food security. The concept of biorefinery has been at the center of attention with an aim to address these challenges by promoting an integral use of biomass to allow the production of multiple products along with biodiesel. Such implementation has been extensively studied over the last years and is expected to lead to economic, environmental, and social advantages over individual processes. The current review first presented an overview on biodiesel, its different feedstocks, and production technologies. Subsequently, the biorefinery concept and its correct implementation was technically discussed. Biodiesel production under the biorefinery scheme was also presented. Finally, techno-economic analysis of biodiesel production under the biorefinery concept by considering palm oil-based biorefinery as case study was investigated.

* Corresponding author at: Tel.: +57 (6) 8879300; Ext. 55354

E-mail address: ccardonaal@unal.edu.co

Please cite this article as: Botero C.D., Restrepo D.L., Cardona C.A. A comprehensive review on the implementation of the biorefinery concept in biodiesel production plants. Biofuel Research Journal 15 (2017) 691-703. DOI: 10.18331/BRJ2017.4.3.6 


\section{Contents}

1. Biodiesel

2. Biodiesel production technologies

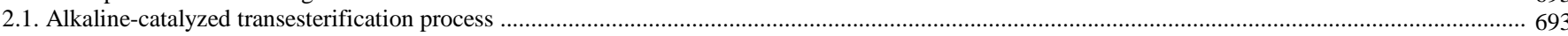

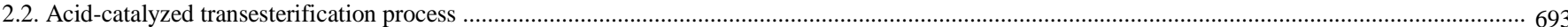

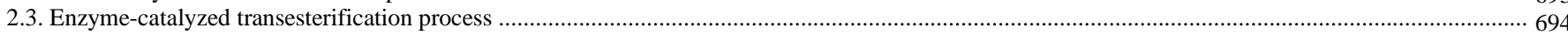

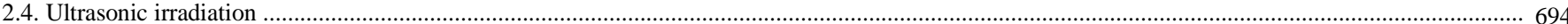

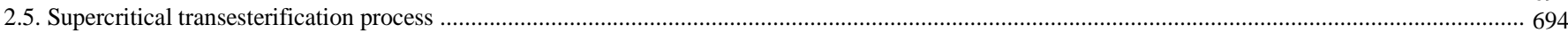

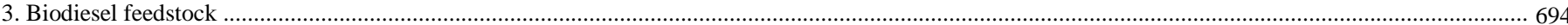

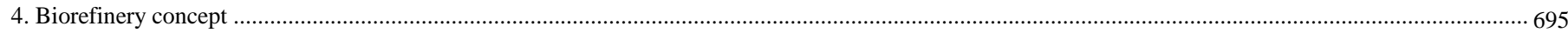

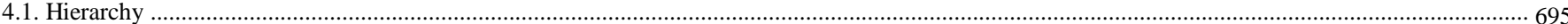

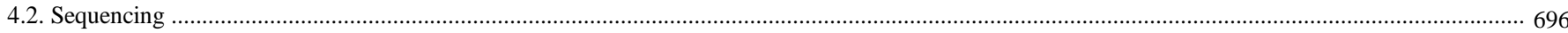

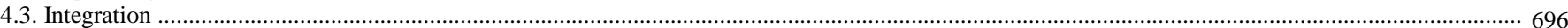

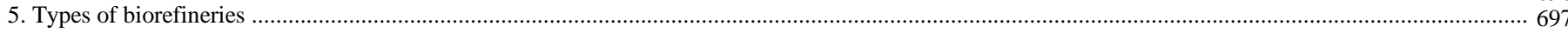

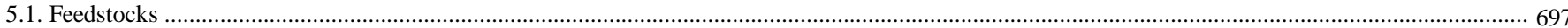

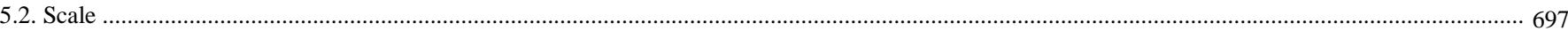

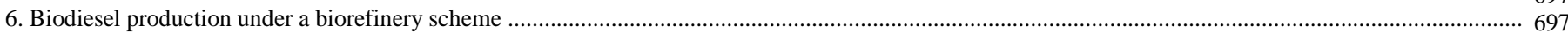

7. Techno-economic analysis of biodiesel production under biorefinery concept: palm oil-based biorefinery as case study .................................................. 698

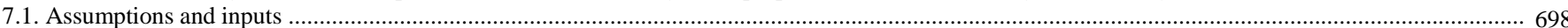

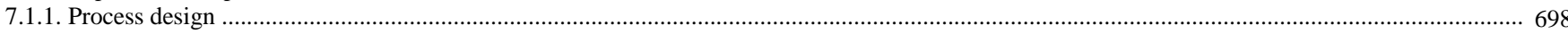

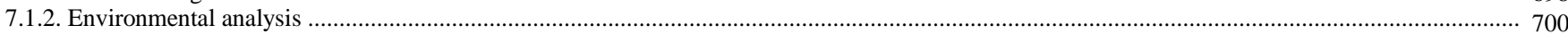

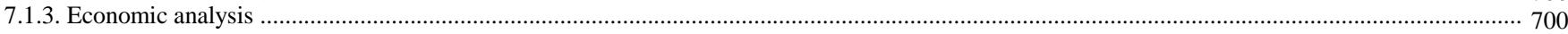

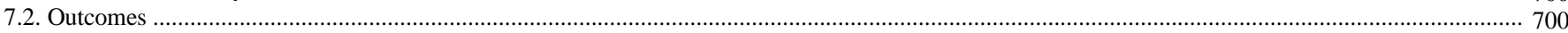

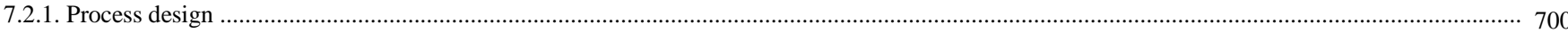

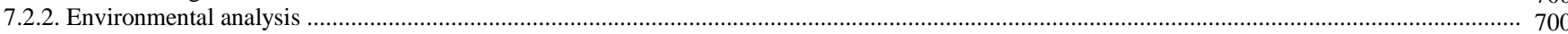

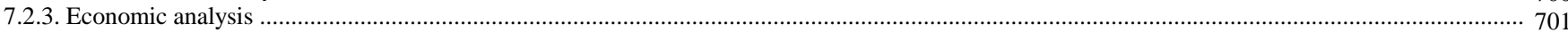

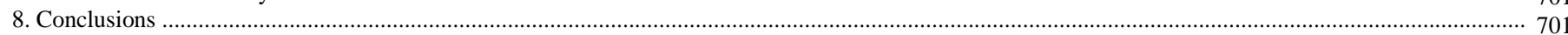

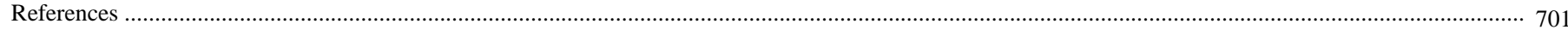

\section{Biodiesel}

The indiscriminate use of non-renewable energy resources over the last decades has been a subject of controversial debates from different perspectives such as their possible exhaustion in the future and/or the grave environmental impacts caused by their exploitation and subsequent utilization (Woldeyohannes et al., 2016). Nevertheless, the international market is still dependent on mineral oil, both for the production of transportation fuels and different chemical products (Moncada and Aristizábal, 2016; Xie et al., 2016). On the other hand, this dependency is believed to further increase owing to population growth, expansion of transportation, and the growing industrialization (Meher et al., 2006). It should also be noted that despite recent developments in oil production thanks to the emerging technologies, there is still a clear uncertainty on the actual exploitable amount of such resources (Christenson et al., 2017). Moreover, a great deal of the world's oil reserves are located in places with political instability further complicating the future of global energy security (Serna et al., 2016).

For these reasons, the search for new alternatives to produce fuels, electricity, and chemicals from renewable raw materials has been on the global research agenda for decades now (Chew et al., 2017). In fact, this dates back the end of the nineteenth century, when it was emphasized that one of the main objectives for the future would be to obtain an economy and processes based on the use of renewable resources, such as biomass, to achieve a sustainable development (Ghatak et al., 2011). In order to fulfill these objectives, different definitions for the term "sustainable development" have been presented ever since. The World Commission on Environment and Development (WCDE) defines sustainable development as "development that meets the needs of the present without compromising the ability of future generations to meet their own needs" (Ghatak et al., 2011). For its part, the UN in 1992 stressed the importance of sustainable development and promulgated that "the right to development must be fulfilled so as to equitably meet developmental and environmental needs of present and future generations" (Ghatak et al., 2011). In line with that, the World Summit on Sustainable Development in the year 2002 set the goal of sustainable development as "access to reliable, affordable, economically viable, socially acceptable, and environmentally sound energy services and resources" (Ghatak et al., 2011). Biofuels for sure are an indispensable part of any agenda aimed at reaching the ultimate goals of sustainable development provided that they in no way compromise the very essential principles of sustainability.
Among various types of biofuesl, biodiesel has attracted a great deal of attention worldwide due to its unique features. Biodiesel, also known as fatty acid alkyl esters, is an oxygenated biofuel, obtained through the transesterification reaction of triglycerides present in vegetables oils and animal fats with a short chain alcohol (i.e., methanol or ethanol) in the presence of a catalyst (homogenous or heterogeneous) with glycerol as coproduct (Montoya et al., 2006).

\section{Table 1.}

Properties of biodiesel according to the ASTM D 6751 standard (ASTM D6751, 2007; Math et al., 2010).

\begin{tabular}{lll}
\hline Property & Limits & Units \\
\hline Calcium \& Magnesium, Combined & $5 \mathrm{max}$ & $\mathrm{ppm}$ \\
Flash Point & $93 \mathrm{~min}$ & ${ }^{\circ} \mathrm{C}$ \\
Methanol Content & $0.2 \mathrm{max}$ & $\%$ Volume \\
Flash Point & $130 \mathrm{~min}$ & ${ }^{\circ} \mathrm{C}$ \\
Water \& Sediment & $0.05 \mathrm{max}$ & $\%$ volume \\
Kinematic Viscosity, $40^{\circ} \mathrm{C}$ & $1.9-6.0$ & $\mathrm{~mm}^{2} / \mathrm{s}$ \\
Sulfated Ash & $0.02 \mathrm{max}$ & $\%$ mass \\
Sulfur & & \\
S 15 Grade & $0.0015 \mathrm{max}$ & $\%$ max $(\mathrm{ppm})$ \\
S 500 Grade & $0.05 \max$ & $\%$ max $(\mathrm{ppm})$ \\
Copper Strip Corrosion & No. 3 max & - \\
Cetane Number & $47 \min$ & - \\
Cloud Point & Report & ${ }^{\circ} \mathrm{C}$ \\
Carbon Residue $100 \%$ sample & $0.05 \max$ & $\%$ mass \\
Acid Number & $0.50 \max$ & $\mathrm{mg} \mathrm{KOH} / \mathrm{g}$ \\
Free Glycerin & $0.020 \max$ & $\%$ mass \\
Total Glycerin & $0.240 \max$ & $\%$ mass \\
Phosphorus Content & $0.001 \mathrm{max}$ & $\%$ mass \\
\hline
\end{tabular}

Biodiesel is regarded as a promising alternative to petroleum diesel and hence, a great deal of attention has been being paid to its various aspects of production and widespread market. Some characteristics of biodiesel as required by international standards are presented in the Table 1 (ASTM D6751, 2007). Figure 1 shows the growing trend of biodiesel consumption in the world. As presented, biodiesel consumption grew by more than 29 folds from the year 2000 to the year 2012 confirming the overall acceptance 
of this renewable energy carrier worldwide (IndexMundi Statistics, 2017). As depicted in Figure 2, the largest biodiesel production in the year 2012 took place in Europe accounting for approximately $52 \%$ of the global production

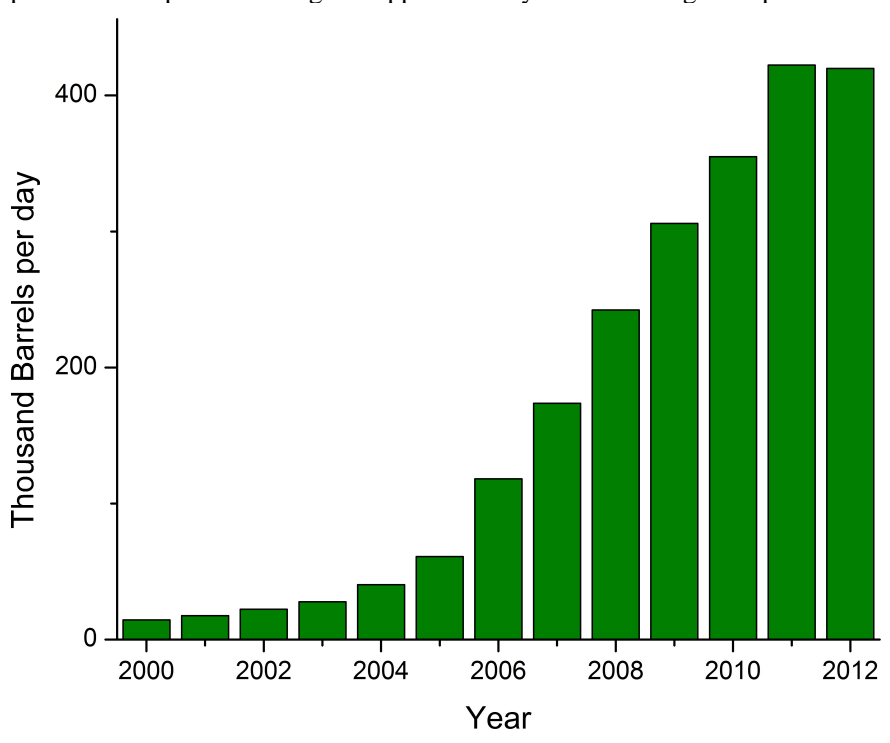

Fig.1. Global trend of biodiesel consumption (IndexMundi Statistics, 2017).

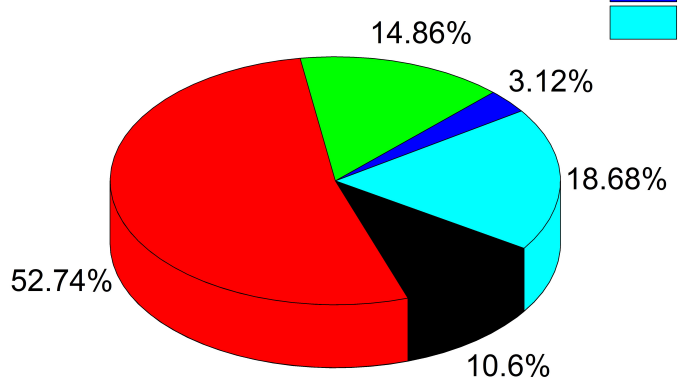

Asia

Europe North America Oceania South America

Fig.2. Worldwide distribution of biodiesel production in the year 2012 (IndexMundi Statistics, 2017).

It should be noted that the majority of energy consumption occurs in the transportation sector and that this sector is heavily dependent on fossil-oriented fuels leading to a great deal of environmental consumption. Tking Columbia as an example, as shown in Figure 3, over $40 \%$ of the energy consumption is associated with the transportation sector where different energy carriers are used. More specifically, diesel (in Spanish: Aceite Combustible para Motores; ACPM) and gasoline make up $37.65 \%$ and $39.78 \%$ of the energy supplied in Columbia, respectively, while biodiesel only represents $3.87 \%$ of the market (Fig. 4).

\section{Biodiesel production technologies}

Biodiesel is produced through different technologies which differ from one another in terms of the type of catalyst employed and the conditions under which the transesterification process is carried out. These differences lead to the formation of different by-products which consequently necessitate different separation/purification stages. Some of the existing production technologies are briefly described herein as examples:

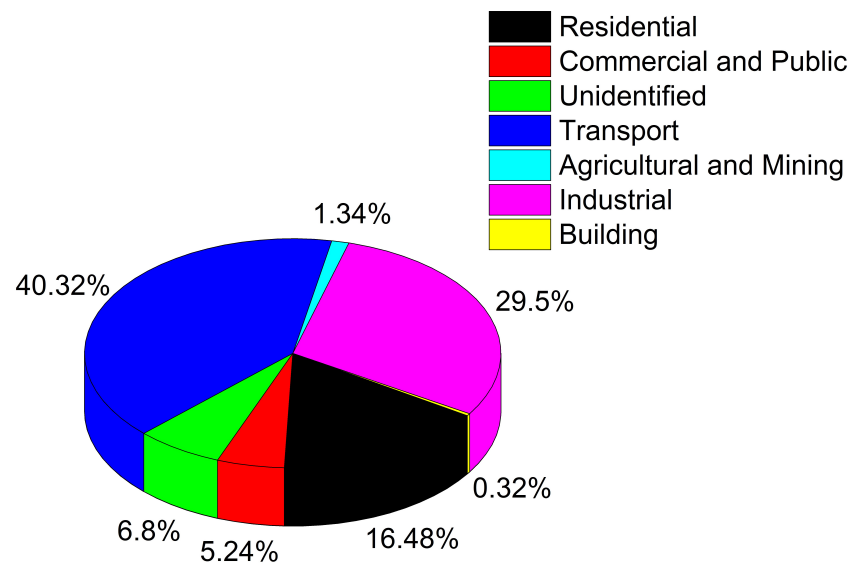

Fig.3. Distribution of energy consumption by sector in Colombia in the year 2015 (UPME, 2016).

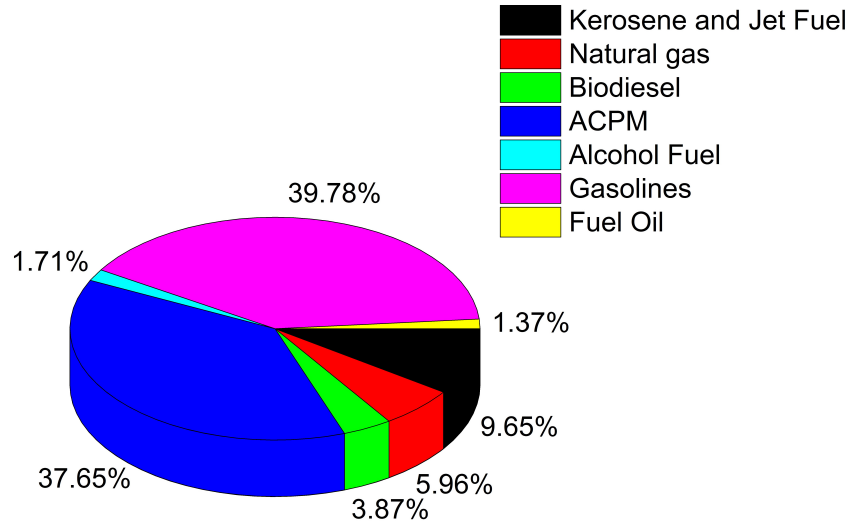

Fig.4. Distribution of energy supply in the transportion sector in Colombia (UPME, 2016).

\subsection{Alkaline-catalyzed transesterification process}

In this type of process, catalyst $\mathrm{s}$ such as sodium methoxide, sodium hydroxide, potassium hydroxide, and potassium methoxide are employed. This process is widely used because it requires moderate temperatures and low pressures and reaches a general conversion rate of $98 \%$. Moreover, the process requires reasonable little time and no intermediate stages are required. This process is highly effective when handling oil feedstocks of less than $1 \%$ free fatty acid (FFA) contents. However, higher FFA contents could result in soap formation which consequently hinders the separation process of the esters and reduces the conversion rate (Canakci and Gerpen, 2001; Math et al., 2010).

\subsection{Acid-catalyzed transesterification process}

The catalyst used in this type of process is an acid such as sulfuric acid, phosphoric acid, hydrochloric acid or an organic sulfonic acid. The acid used could catalyze the esterification of FFAs at a relatively fast rate while the transesterification of triglycerides is carried out at a slower rate. However, no soap formation is experiences which elevate the challenges faced with the application of alkaline catalysts such as esters loss and high water consumption during downstream purification processes. To achieve an accelerated reaction rate, this process needs to be carried out at high temperatures and long reaction times will be required. On the other hand, corrosion the equipment used is also regarded as a disadvantage of this method (Helwani et al., 2009; Santacesaria et al., 2012; Thanh et al., 2012). 


\subsection{Enzyme-catalyzed transesterification process}

A biocatalytic alternative for the production of biodiesel includes the use of enzymes such as lipases. In this context, the advantages are no byproducts generation, ease of production separation, and moderate operating conditions $\left(35-45^{\circ} \mathrm{C}\right)$. Different lipases obtained from different microorganisms such as Mucor meihi, Candida antartica, Geotrichum candidum, and Pseudomonas cepacia have been frequently used as catalysts for the transesterification of various oil feedstocks such as olive oil, soybean oil, tallow, etc. One of the disadvantages of this process is the high costs of lipases. Strategies such as enzyme immobilization have been laid forth with an aim to address this challenges; more research would be required before economically-feasible large-scale commercialization could be realized though (Helwani et al., 2009; Thanh et al., 2012)

\subsection{Ultrasonic irradiation}

Since immiscible phases, i.e., oil and alcohol are involved in the transesterification reaction; ultrasound irradiations have been presented as efficient tool to facilitate mass transfer and consequently the efficiency of the reaction. In fact, ultrasonic irradiations cause cavitation of bubbles near the phase boundary between immiscible liquid phases. The asymmetric collapse of the cavitation bubbles disrupts the phase boundary and instantly starts the emulsification. As a result, the alcohol and oil bubbles are sufficiently close for the transesterification reaction to be carried out more easily. Consequently, lower amounts of catalyst and methanol would be required compared with conventionaly-mixed methods (Sarkar and Bhattacharyya, 2012; Thanh et al., 2012).

\subsection{Supercritical transesterification process}

In the transesterification of any oil feedstocks, the presence of water can favor the formation of soap and the deactivation of the catalyst. However, water could exert positive effects when supercritical fluids are used, as it promotes the mechanism of reaction. In fact, in this process, no catalyst is required, and thus catalyst recovery process and separation of by-products are unnecessary. Reaction times are shorter $(2-4 \mathrm{~min})$ than conventional catalytic transesterification and a high conversion rate is expected. The conditions of this process are between $300-400{ }^{\circ} \mathrm{C}$ and about $80 \mathrm{~atm}$ (Helwani et al., 2009; Thanh et al., 2012). Table 2 tabulates the operating conditions and the general yields of the above-mentioned technologies for the production of biodiesel.

\section{Biodiesel feedstock}

Raw materials used in biodiesel production account for approximately over $70 \%$ of the total production cost (Math et al., 2010). Therefore, it is necessary to study different options to enhance the economic aspects of the final product, i.e., biodiesel as much as possible. In general, availability and low acquisition cost are regarded as the most important criteria for a sustainable biodiesel feedstock. These differ in different countries around the world. It is also important that the utilization of a given feedstock will not trigger concerns in terms of food security.

For instance, in Argentina, soybean is the preferred feedstock for biodiesel production due to its low cost, while in China, this feedstock is not considered a promising biodiesel feedstock due to the high demands for soybean oil as an important ingredient of traditional Chinese cuisine.
Table 2.

Operating conditions for some transesterification technologies (Leung et al., 2010; Math et al., 2010)

\begin{tabular}{llllll}
\hline \multirow{2}{*}{ Parameter } & \multicolumn{5}{c}{ Transesterification technology } \\
\cline { 2 - 6 } & $\begin{array}{l}\text { Alkaline- } \\
\text { catalyzed }\end{array}$ & $\begin{array}{l}\text { Acid- } \\
\text { catalyzed }\end{array}$ & $\begin{array}{l}\text { Enzyme- } \\
\text { catalyzed }\end{array}$ & $\begin{array}{l}\text { Ultrasonic } \\
\text { irradiation }\end{array}$ & Supercritical \\
\hline $\begin{array}{l}\text { Reaction } \\
\text { temperature }\left({ }^{\circ} \mathrm{C}\right)\end{array}$ & $60-70$ & $55-80$ & $30-40$ & $10-60$ & $300-400$ \\
$\begin{array}{l}\text { Reaction time } \\
\text { (min) }\end{array}$ & 60 & 240 & $\begin{array}{l}480- \\
4,200\end{array}$ & $30-600$ & $2-4$ \\
$\begin{array}{l}\text { Reaction pressure } \\
(\mathrm{MPa})\end{array}$ & $0.14-0.41$ & 0.4 & 0.1 & 0.1 & $8-25$ \\
$\begin{array}{l}\text { Type of catalyst } \\
\begin{array}{l}\text { Methyl esters } \\
\text { yield }\end{array}\end{array}$ & $\mathrm{NaOH}$ & $\mathrm{H}_{2} \mathrm{SO}_{4}$ & $\mathrm{Lipase}$ & $\mathrm{H}_{2} \mathrm{SO}_{4}-\mathrm{NaOH}$ & $\mathrm{None}$ \\
\hline
\end{tabular}

For similar reasons, feedstocks such as jatropha, castor bean, and karanja have attracted attention in countries such as India and Brazil (Rincón et al., 2014), waste cooking oil in Japan, and tallow and animal fats in Canada and Australia (Bhattacharyya, 2011). Non-edible oil crops are also considered promising biodiesel feedstock in many parts of the world as they make possible harnessing marginal lands, preserving most productive lands for food production (Barnwal and Sharma, 2005). Nevertheless and in spite of their economically-favorable features, non-edible oil feedstock usually suffer from a number of disadvantages such as high FFA contents and consequently low solidification points at room temperature, causing difficulties during biodiesel production and use (Dias et al., 2008; Leung et al., 2010). Different microalgal species have also been highlighted as biodiesel feedstock owing to their high comparative potentials, i.e., high production rates, high oil contents, and low land requirements (Mata et al., 2010; Huang et al., 2010). However, to important constraints faced, their realistic short- and mid-term commercialization has been seriously questioned (Chisti, 2013). Moreover, microalgal oil could be the source of a number of added-value products such as omega 3 fatty acids and therefore, it would be more economically justified to use them for such purposes rather than as biodiesel feedstock.

Table 3 presents the composition of a number of oil feedstocks used for biodiesel production. Among these, palm oil seems the most promising given its large global production. More specifically, in the year 2010 more than 45.7 million tons of palm oil were produced globally and this value is expected to increase to 64 million tons by the year 2020. However, it should be noted that palm oil is one of the main sources of edible oil in the world as well and almost $90 \%$ is currently used for food consumption while about $10 \%$ is being used for non-food applications such as biodiesel (Quintero et al., 2012). The major producers of palm oil are Malaysia and Indonesia contributing $83 \%$ of the global production but the crop is also grown widely in other tropical countries such as Colombia standing as the fourth world producer of palm oil due to its favorable agro-ecological conditions. Upon the extraction of palm oil, significant amounts of lignocellulosic residues are also generated which could serve as feedstock for lingo-ethanol production through a biorefinery platform. More specifically, the on-site generated lingo-ethanol could be used in the biodiesel production process from palm oil (Gutiérrez et al., 2009). Under the concept of biorefinery and through the integration of different processes, apart from biodiesel and lingo-ethanol, other value-added products such as xylitol, synthesis gas, butanol, biogas, and furfural, among others, could also be obtained.

Table 3.

Fatty acid composition of major oil feedstocks used for biodiesel production (Marchetti et al., 2009; Fassinou, 2012).

\begin{tabular}{lllllllll}
\hline Fatty acid & Soybean & Cotton seed & Palm & Lard & Tallow & Coconut & Sunflower & Jatropha \\
\hline Lauric & 0.1 & 0.1 & 0.1 & 0.1 & 0.1 & 46.5 & 0.0 & 0.0 \\
Myristic & 0.1 & 0.7 & 1.0 & 1.4 & 2.8 & 19.2 & 0.0 & 0.0 \\
Palmitic & 10.2 & 20.1 & 42.8 & 23.6 & 23.3 & 9.8 & 6.4 & 4.1 \\
Palmitoleic & 0.0 & 0.0 & 0.0 & 0.0 & 0.0 & 0.0 & 0.1 & 13.8 \\
Stearic & 3.7 & 2.6 & 4.5 & 14.2 & 19.4 & 3.0 & 2.9 & 6.7 \\
Oleic & 22.8 & 19.2 & 40.5 & 44.2 & 42.4 & 6.9 & 17.7 & 42.0 \\
Linoleic & 53.7 & 55.2 & 10.1 & 10.7 & 2.9 & 2.2 & 72.9 & 33.4 \\
Linolenic & 8.6 & 0.6 & 0.2 & 0.4 & 0.9 & 0.0 & 0.0 & 0.0 \\
\hline
\end{tabular}




\section{Biorefinery concept}

The integral use of biomass for the production of value-added compounds such as biomaterials and chemical compounds, also known as biorefinery concept, has been of great importance in the chemical industry in general (Cherubini et al., 2010). Nevertheless, in the biofuels industry, biomass has been mostly used for the production of biofuels with an aim to partially or completely replace highly polluting fossil-oriented fuels. Over the last decades, the integral use of biomass for the production of a broader spectrum of addedvalue products in addition to biofuels, such as biomaterials, fine chemicals, biopolymers, etc. has presented new opportunities not only to enhance the environmental aspects of the biofuels industry but also to improve the economic aspects of biofuels production (Cherubini et al., 2010). In fact, these developments have led to the prediction that the existing oil-based economy will be gradually replaced by a biomass-based economy (Cherubini et al., 2010).

The first applications of biomass were inefficient, i.e., low conversion of the raw materials to products of interest along with the high amounts of residues generated (Moncada and Aristizábal, 2016). For instance, for the production of essential oils, only $1-2 \%$ of the raw material would lead to the final product while the remaining 98\% would end up as process waste (Moncada and Aristizábal, 2016). As a result, the idea of biomass exploitation would in principle contradict what generally sought by process designers, i.e., generating low levels of pollution during biomass transformation and high economic benefits. Subsequently, the integral use of biomass was brought into attention as a fundamental part of any biotechnological processes involving biomass in order to reduce environmental impacts, increase economic benefits, and to generate positive social impacts on rural communities (Moncada and Aristizábal, 2016).

In line with that, numerous efforts with a biorefinery focus have been to date made (Cherubini et al., 2010; Ghatak et al., 2011; Moncada and Aristizábal, 2016). International Energy and Bioenergy Agency (IEA) task 42 defines a biorefinery as the "sustainable processing of biomass into a spectrum of marketable products (food, feed, materials, and chemicals) and energy (fuels, power, and heat)" (Ghatak et al., 2011). Some authors have also tried to further break down this definition proposing their own versions. For instance, Cherubini et al. (2010) describes biorefinery as "a facility (or network of facilities) that integrates conversion processes and equipment to break down biomass resources (wood, grasses, corn, etc.) into their building blocks (carbohydrates, proteins, triglycerides, etc.) and subsequently converted them into value-added products such as biofuels and chemicals".

From the above definitions, it can be understood that a biorefinery is in general a system in which the constituents of biomass must be harnessed as much as possible to produce a range of products, an analogous concept to oil refineries (Cherubini et al., 2010; Moncada and Aristizábal., 2016). Nevertheless, although the concept of biorefinery is an adaptation of the concept of refinery, these have large differences (Moncada and Aristizábal, 2016). First, the raw materials are completely different, because although biomass and oil are rich in carbon, biomass is obtained from living or recently living materials while crude oil is a compound obtained after millions of years of biodegradation (Moncada and Aristizábal, 2016). In another word, biomass is a renewable resource produced indigenously in different quantities various geographical locations in the world, contrary to crude oil (Cherubini et al,, 2010). The second difference is based on their complexity as biorefineries apply and integrate a large number of mature and emerging technologies for obtaining different products (Moncada and Aristizábal, 2016). The third difference lies in the broad spectrum of products obtained in biorefineries including food-grade products which cannot be obtained from petroleum refineries (Moncada and Aristizábal, 2016).

Due to the above-mentioned advantages, biorefineries are very versatile and can be adapted according to the desired needs or objectives. In most cases, biorefineries are designed to meet three main objectives. The first objective would be to ensure energy security in both the developed and developing countries where a large volume of biomass is produced (Martinez-Hernandez et al., 2013). The second objective would be reduction of environmental impacts associated with the production of chemical products by using renewable resources and processes, i.e., less waste generation and less greenhouse gases emissions (Cherubini and Ulgiati, 2010). And the third objective would be rural development and an increase in the quality of the life of the communities involved in the supply chain of these products (Cherubini et al., 2010). Nevertheless, to achieve these three objectives mentioned, development of conceptual bio refinery designs is essential. In better words, in order to be able to identify a sum of processes and technologies as a biorefinery, it must be designed as such from the very beginning (Moncada and Aristizábal, 2016). This means that if a stand-alone process would be added to another process in order to obtain an added-value product, this should at no time be considered as a biorefinery, since it is only a combination of stand-alone processes and was not designed under the biorefinery concept (Moncada and Aristizábal, 2016). To design a biorefinery, different approaches have been presented in the literature. Among the most widely used approaches are superstructures, conceptual design, and optimization (Zondervan et al., 2011). These approaches could well interact with each other.

In order to clarify the design process, efforts have been made to develop a design strategy that can be followed step by step to obtain a biorefinery of ideal economic, environmental, and social characteristics (Cardona et al., 2016). A methodology proposed by Cardona et al. (2016) for designing biorefineries takes into account three essential factors, i.e., hierarchy, sequencing, as well as energy and mass integration. These concepts are presented herein in more detail.

\subsection{Hierarchy}

The hierarchy is the stage of the design of a biorefinery in which the hierarchical decomposition of the raw materials, products, and technologies is performed (Cardona et al., 2016). Any biorefineries is first obliged to select the raw materials needed to obtain products of interest (Cardona et al., 2016). This selection is not a simple process as it would depend on the availability, political situations, geographic features, and other factors previously described (Cardona et al., 2016). For this reason, the selection of the raw material implies a direct relation with the products because each raw material can be decomposed into different buildings blocks (e.g., sugars) that will later be transformed into added-value products through a series of technologies (Moncada and Aristizábal, 2016). In addition, the raw materials selected for use in biorefineries can be separated according to their generation, where each generation has specific characteristics (Naik et al., 2010). In this sense, many authors stress that the selection of feedstocks generation could be an important part of a biorefinery design since its economic, social, and environmental aspects would be severely affected accordingly (Naik et al., 2010).

On the other hand, limiting the process to a generation of raw material does not comply with the objectives of a biorefinery, on the contrary, combination of generations where possible, could lead a biorefinery towards integral use of all raw materials available (Ghatak et al., 2011). An example of this is the production of biodiesel from oil palm. In this process, oil is produced for edible purposes while a proportion is converted into biodiesel by means of the transesterification process, i.e., the reaction of oil with a monohydric alcohol in presence of a catalyst (Meher et al., 2006; Rincón et al., 2014). But if the lignocellulosic residues remained after oil extraction would be used for the production of bioethanol, the combination of first and second generation feedstocks, i.e., palm oil and ligno-ethanol, respectively, could provide better economic and environmental aspects to the process (Rincón et al., 2014).

Having the raw material/s defined, the next step in the design of the biorefinery would be to realize the technologies to be applied in the transformation of biomass. For biomass transformation, there are four main pathways technologically available, i.e., thermochemical, biochemical, chemical, and physical (Moncada and Aristizábal, 2016).

Finally, the hierarchy also involves the selection of the product/s of interest as an essential part of the design of a biorefinery (Cardona et al., 2016). In a biorefinery, high-volume but low-cost products such as biofuels and/or low-volume products with a very high added-value (such as pharmaceutical products and fine chemicals) could be achieved (Cardona et al., 2016). The selection of products of interest would depend on the decision of the designer and the available technologies and raw materials (Cardona et al., 2016). It is needless to stress that all the steps of the hierarchy must be interconnected properly and efficiently in order to obtain a sustainable biorefinery. Figure 5 presents the conceptual scheme of the hierarchy in a biorefinery. 


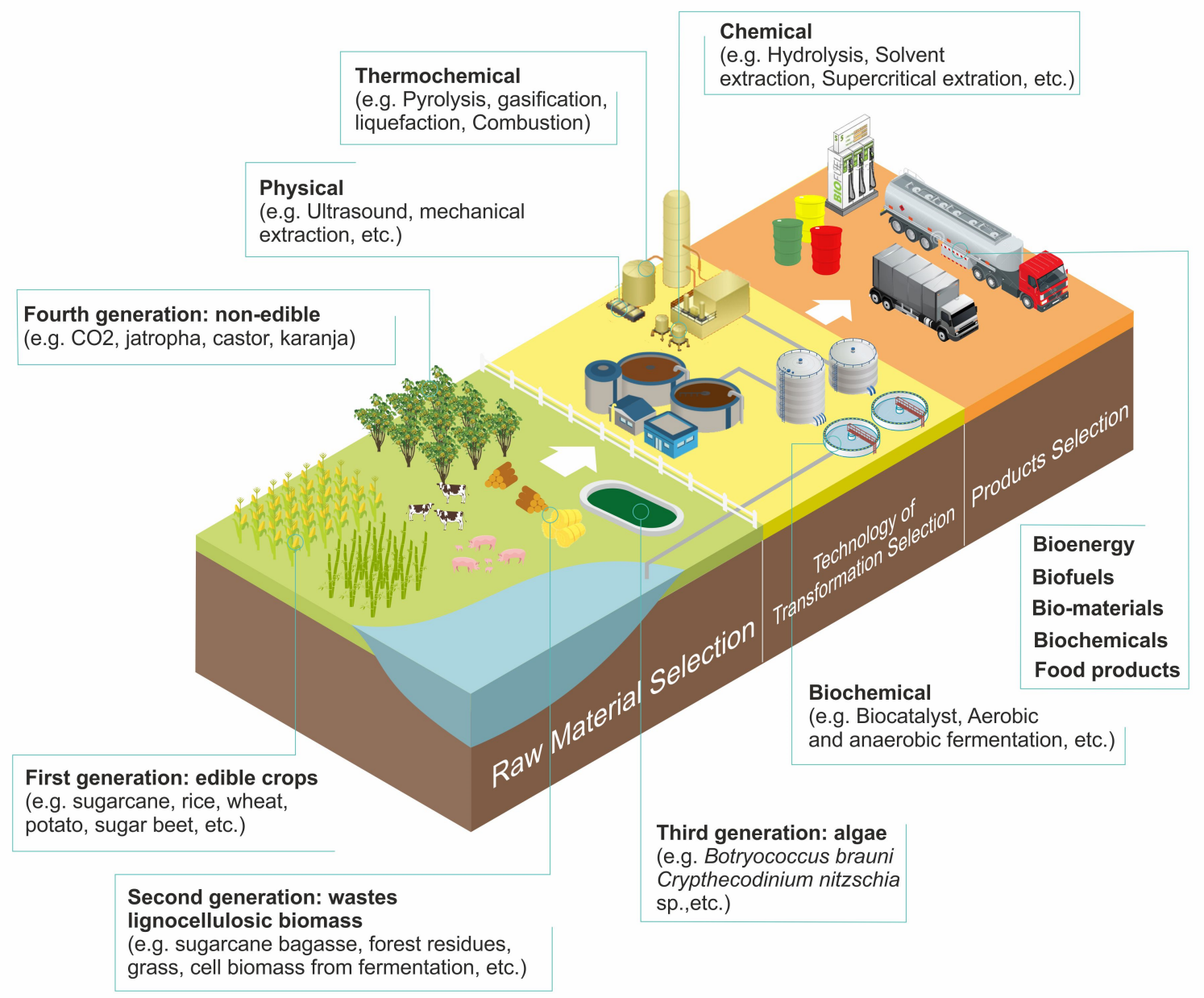

Fig.5. Scheme of the hierarchy of a biorefinery.

\subsection{Sequencing}

Sequencing is the stage where a logical sequence is given to the technologies used and products to be obtained (Moncada et al., 2014). That is to say, if what is wanted in a biorefinery is to obtain energy products, this implies that some technologies are discarded, reducing the options of possible sequences (Moncada et al., 2014; Cardona et al., 2016). Finding the optimal sequence for a biorefinery is not an easy case, since the possibilities of sequences can be multiple. Therefore, it is important to define the most interesting products (Moncada and Aristizábal, 2016).

In sequencing, it is also important that certain distribution rates are given to different raw materials and buildings block products, in order to give priority to specific ones (Moncada et al., 2014; Cardona et al., 2016; Moncada and Aristizábal, 2016). In the same sense, it is a golden rule that when designing a biorefinery, food products must be in the first steps of the biorefinery sequence; this will avoid possible contamination with substances used in the synthesis of other products (Moncada and Aristizábal, 2016). In addition, the products must be obtained with the highest purity possible, to generate less wastes and consequently lower environmental impacts (Moncada et al., 2014; Cardona et al., 2016; Moncada and Aristizábal, 2016).

\subsection{Integration}

The integration aims at an integral use of the mass, energy and in general the resources present inside a given plant. In this sense, the integration of a biorefinery is classified into three levels (Cardona et al., 2016; Moncada and
Aristizábal, 2016). (i) Integration of feedstocks, (ii) integration of technologies, and (iii) integration of products.

Mass integration is based on the integral use of materials. That is to say, the residues coming from a process in a biorefinery will be again used as raw materials in a subsequent process (Moncada et al., 2014). As an example, in the palm oil extraction process, the lignocellulosic residues obtained are called empty fruit bunches (EFB) and can be transformed by different technologies into ethanol, butanol, and/or electricity, just to name a few products (Serna et al., 2016). In turn, the ethanol produced can be used for the production of biodiesel, or the oil product of the extraction process can be used in part for the production of antioxidants and biodiesel (Cardona et al., 2016). All different types of integration of raw materials would allow minimizing the produced wastes.

The integration of technologies is mostly based on the use of technologies to exploit energy resources, seeking to improve environmental and economic aspects of the biorefinery (Zondervan et al., 2011). The integration of heat, through pinch technologies, allows using the energy that is released in a process, exploiting it in the preheating of raw materials or other processes that require heat (Martinez-Hernandez et al., 2013). This would give great economic benefits to biorefineries, since the high consumption of energy resources is one of the weaknesses of biorefineries (Martinez-Hernandez et al., 2013). The recycling of water resources used in washing equipment, or in other functions which would not lead to significant contamination would allow the used water to be treated and reused in the processes. The integration of technologies is also related to the intensification of processes, so that the biorefinery will be as compact and efficient as the design allows (Long et al., 2016). 


\section{Types of biorefineries}

As mentioned above, there is a direct relationship between the raw material used, products achieved, and technologies implemented in a biorefinery. Nevertheless, a biorefinery can be classified into different types based on raw material and production scale (Naik et al., 2010). As for raw materials, i.e., feedstocks, a biorefinery can be classified in first, second, third, and fourth generation biorefinery, which will be explained as follows.

\subsection{Feedstocks}

Each raw material designates a biorefinery with a different feature. For a biorefinery to be reliable and comparable to the oil refinery, it must have a constant and assured supply of raw material (Ghatak et al., 2011). The availability of biomass is related to geographical, political, social, and, above all, economic and logistical aspects (Ghatak et al., 2011). In this sense, the biomass has been differentiated in generations to give clarity to the factors related to each raw material. The first generation feedstocks are those that contradict food safety, meaning crops used for human consumption as well, such as edible oil, sugar or starch (Moncada et al., 2013). The use of first generation feedstocks can threaten food security by increasing the cost of edible crops and by triggering a competition over water and land. For this reason, doubts arise with respect to the sustainable use of these raw materials in long term (Moncada et al., 2013).

Second generation feedstocks are those that are generated as waste in agroindustry, agriculture, forestry, as well as household and other industries, e.g., waste cooking oil, among others (Mathioudakis et al., 2017). Second generation feedstocks provide biorefineries with great advantages because of their low cost; it should be noted that in a typical biorefinery, the costs of raw materials account for 40 to $60 \%$ of the total costs involved (Ghatak et al., 2011). Additionally, the use of second generation feedstocks is associated with environmental improvements (Mata et al., 2010). Another important aspect attributed to the use of second generation feedstocks is rural areas development (Mata et al., 2010)

Third generation feedstocks include algae as some algal species are rich sources of oils, which can be used in the production of biofuels such as biodiesel (Mata et al., 2010). It has also been demonstrated that from the oil obtained from these organisms, a number of products of high added-value could be obtained such as docosahexanoic acid (Trivedi et al., 2015). However, there are serious constraints to commercially-viable production of algal fuels which have been comprehensively discussed previously by Chisti (2013). The forth generation of feedstocks include carbon dioxide generated through industrial processes and regarded as pollutant which could be used as a feedstock in biorefineries and presents interesting environmental and economic benefits (Mata et al., 2010). Moreover, the crops grown in marginal lands without common agricultural practice requirements such as irrigation could also be categorized under fourth generation feedstocks (Moncada and Aristizábal, 2016). Table 4 shows examples of the different raw materials belonging to different feedstock generations.

\subsection{Scale}

Biorefineries can be designed at different scales, but this must be directly related to the products to be obtained. In another word, when it comes to high added-value products such as fine chemicals, the scale may be small, but if what is to be obtained are biofuels, the scale must necessarily be large (Cardona et al., 2016). Many authors have pointed out that biorefineries are very sensitive to scale changes (Cardona et al., 2016). There are different factors affecting the scale of a biorefinery including the availability of raw materials, production costs, and net present value (Cardona et al., 2016).

\section{Biodiesel production under a biorefinery scheme}

The production of biodiesel and bioethanol by countries such as Brazil, Colombia, United States, Indonesia, India as well as new players such as China has led to a significant boost in the supply of these renewable energy carriers in the market over the last decade. On the other hand, expansion of global transportation system and its vast energy requirements has also been an important factor in promoting the use of these fuels (Mata et al., 2010). Biodiesel and bioethanol are either used as additives to diesel or gasoline, or in some cases, they are fed directly into engines with less or without modifications (Mata et al., 2010). For the production of biodiesel, various generations of oil feedstocks are used including oil palm, sunflower, canola, soybean, waste cooking oil, as well as algae and inedible crops such as jatropha (Moncada and Aristizábal, 2016).

In the production of biodiesel from oil palm for instance, oil extraction involves the generation of a large quantity of lignocellulosic residues such as empty fruit bunches, kernel and cake press (Cardona et al., 2016). For this reason, the production of biodiesel under the concept of biorefinery through which lignocellulosic wastes are also used as raw material for generation of other added-value products could present great economic advantages (Cardona et al., 2016). Among the products that can be obtained in the production of biodiesel under the concept of biorefinery are butanol, ethanol, acetone, furfural, syngas, and electricity, among many others (Cherubini and Ulgiati, 2010; Moncada and Aristizábal, 2016; Cardona et al., 2016). Nevertheless, each biorefinery scheme must be individually evaluated in order to ensure achieving the highest level of sustainability from both economic viability and environmental friendliness. In line with that, the different generations of raw materials and their pros and cons must be scrutinized to generate different schemes for biodiesel producing biorefineries (Naik et al., 2010). Figure 6 presents the production of biodiesel under different generations of biorefinery.

Third and fourth generation feedstocks for biodiesel production, i.e., algae and $\mathrm{CO}_{2} /$ non-edible crops have gained a great interest over the last few years (Mata et al., 2010; Moncada and Aristizábal, 2016). However, the main challenge still to be is the high costs associated with these systems, for instance, algae cultivation for biodiesel production is still not economically justified (Mata et al., 2010). Nevertheless, if algae is used as a raw material under a biorefinery approach, this would allow the

Table 4.

A classification of the different generations of feedstocks which could be used in different types of biorefineries*

\begin{tabular}{|c|c|c|c|c|}
\hline $\begin{array}{l}1^{\text {st }} \text { generation Feedstocks: } \\
\text { edible crops }\end{array}$ & $\begin{array}{l}2^{\text {nd }} \text { generation feedstocks: } \\
\text { waste/residue resources }\end{array}$ & $\begin{array}{l}3^{\text {rd }} \text { generation feedstocks: } \\
\text { algae }\end{array}$ & $\begin{array}{l}4^{\text {th }} \text { generation feedstocks: } \\
\mathrm{CO}_{2} \text { and non-edible crops }\end{array}$ & References \\
\hline $\begin{array}{l}\text { Sugarcane, rice, wheat, } \\
\text { potato, sugar beet, barley, } \\
\text { corn, peanut, soybean, } \\
\text { rapeseed, sunflower, olive, } \\
\text { oil palm etc. }\end{array}$ & $\begin{array}{l}\text { Sugarcane bagasse, forest } \\
\text { residues, grass, fermentation } \\
\text { biomass, wood and wood } \\
\text { wastes, glycerol, black liquor, } \\
\text { crops residues, waste cooking } \\
\text { oil, animals fats, etc. }\end{array}$ & $\begin{array}{l}\text { Botryococcus brauni } \\
\text { Crypthecodinium } \\
\text { Nitzschia } \text { sp. } \\
\text { Phaeodactylum } \\
\text { Schizochytrium } \mathrm{sp} . \\
\text { Tetraselmis suecia } \\
\text { Pavlovalutheri, } \\
\text { Scenedesmus ob. } \\
\text { Spirulina maxima. } \\
\text { Ankistrodesmus sp. } \\
\text { Chaetoceros calcitrans } \\
\text { Chlorella vulgaris } \\
\text { Dunaliella tertiolecta }\end{array}$ & $\begin{array}{l}\mathrm{CO}_{2} \text {, Jatropha, Castor, } \\
\text { Karanja }\end{array}$ & $\begin{array}{l}\text { Patel and Sankhavara (2017); Negm et al. } \\
\text { (2017); Haider et al. (2017); Feyzi et al. } \\
\text { (2017); Rincón et al. (2014); Cherubini and } \\
\text { Ulgiati (2010); Martinez-Hernandez et al. } \\
\text { (2013); González-Delgado et al. (2011); } \\
\text { Sacramento-Rivero et al. (2010); Moncada et } \\
\text { al. (2013); Azad et al. (2015); Posada et al. } \\
\text { (2012); Naik et al. (2010); Mansoornejad et al. } \\
\text { (2010); O'Keeffe et al. (2012); Lü et al. (2011) }\end{array}$ \\
\hline
\end{tabular}

* Adopted from Moncada and Aristizábal (2016) 


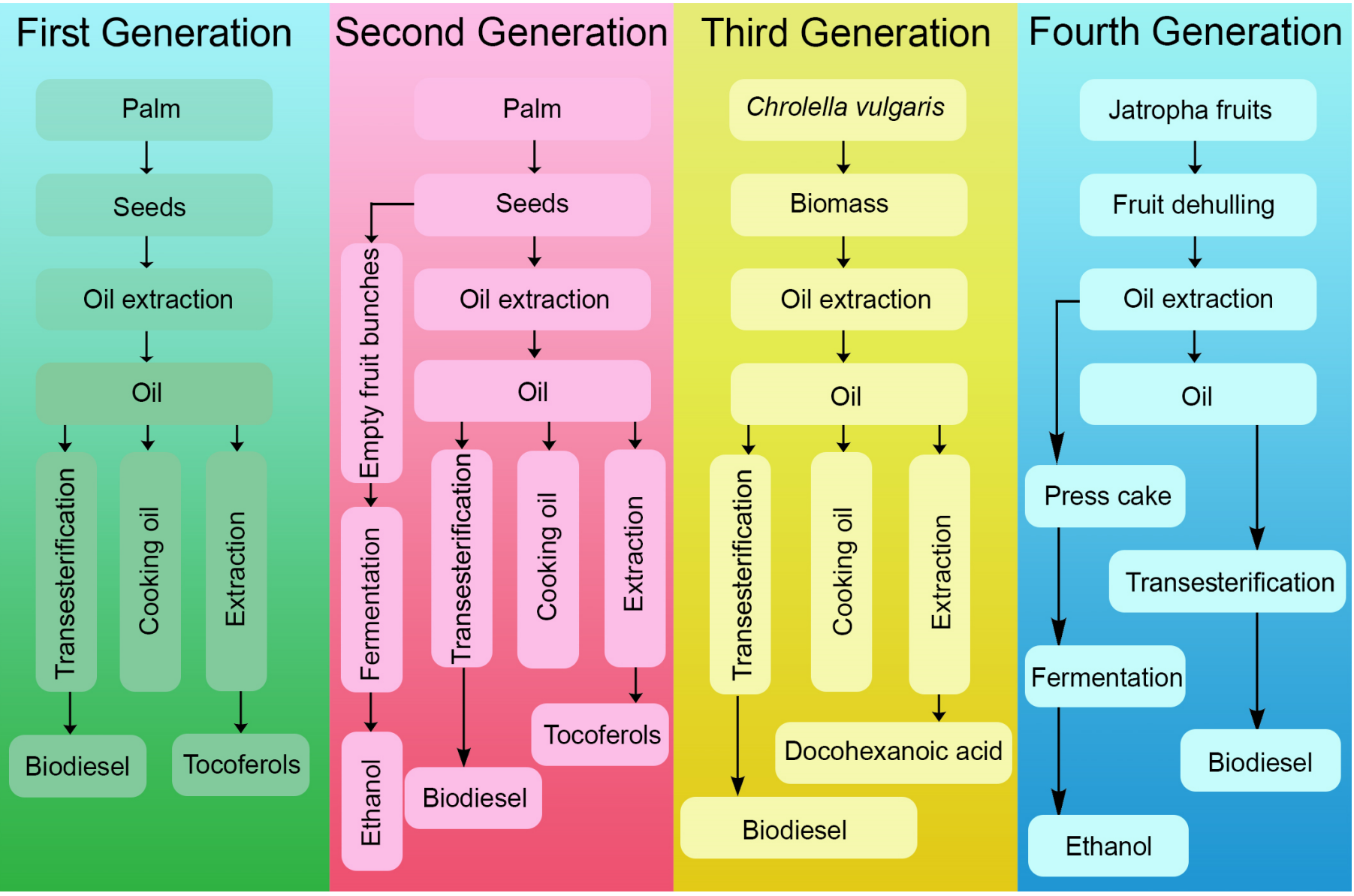

Fig.6. Biodiesel production under different generations of biorefinery.

production of a wider spectrum of products rather than just biodiesel such as docosahexaenoic acid, leading to more favorable economic performance of the system (Trivedi et al., 2015). In spite of that, these types of proposals should also be analyzed in depth, since the additional extraction/separation processes which should be implemented for such components could impose excessive costs on the biorefinery jeopardizing its economic viability (Trivedi et al., 2015). This is also true about non-edible feedstocks in spite of the fact that they can be obtained at low cost by being cultivated on marginal and/or arid lands without agricultural practices (Moncada and Aristizábal, 2016).

7. Techno-economic analysis of biodiesel production under biorefinery concept: palm oil-based biorefinery as case study

\subsection{Assumptions and inputs}

\subsubsection{Process design}

In order to analyze the production of biodiesel under the biorefinery concept, the design of a biorefinery using fresh fruit bunches (FFB) of palm oil as raw material was investigated herein as a case study. Aspen Plus was used for all the simulations and a feed flow of $10,000 \mathrm{~kg} / \mathrm{h}$ was considered. It was proposed to obtain ethanol, biodiesel, xylitol, synthesis gas, and electricity under the investigated biorefinery platform. Glycerol was taken into account as a byproduct of the biorefinery. Table 5 shows the composition of the FFB employed in this work. Table 6 presents the oil composition obtained from FFB used for biodiesel production.

Figure 7 depicts the pretreatment process of the raw material. The FFB was first subjected to a grinding process, reaching a particle size of $1 \mathrm{~mm}$ in diameter. A filtration process was then carried out through which the oil
Table 5.

Oil palm fresh fruit bunch (FFB) composition (Prasertsan and Prasertsan, 1996; Chang, 2014).

\begin{tabular}{lc}
\hline Component & Fraction \\
\hline Cellulose & 0.2370 \\
Hemicellulose & 0.2058 \\
Lignin & 0.1410 \\
Ash & 0.0130 \\
Extractives & 0.0321 \\
Oil & 0.2500 \\
\hline
\end{tabular}

contained within the lignocellulosic material was extracted. Subsequently, the sugars contained in the lignocellulosic residues were released by using a dilute sulfuric acid treatment $(2 \% \mathrm{v} / \mathrm{v})$. The kinetics employed were those previously reported by Aguilar et al. (2002). The resulting solution was filtered, obtaining a liquid fraction (xylose) and solid fraction (cellulose and lignin). The latter was sent to another process involving enzymatic hydrolysis to release the glucose contained within the pulp. For this, the kinetics reported by Philippidis et al. (1993) was employed. The obtained liquor was subjected to a separation process in which a solution rich in glucose was obtained while lignin was remained as solid fraction.

Figure 8 presents the stage of ethanol production from the glucose obtained in the pretreatment stage. For the transformation of glucose into 
Table 6.

Fatty acid composition of oil palm (Seribainun Hidayah et al., 2015).

\begin{tabular}{lc}
\hline Fatty acid & Percent \\
\hline Caprylic & 0.01 \\
Lauric & 0.1 \\
Myristic & 0.94 \\
Palmitic & 42.84 \\
Palmitoleic & 0.19 \\
Stearic & 4.39 \\
Oleic & 40.23 \\
Linoleic & 10.47 \\
Linoleneic & 0.31 \\
Arachidic & 0.37 \\
\hline Behenic & 0.07 \\
\hline Lignoceric & 0.1 \\
\hline
\end{tabular}

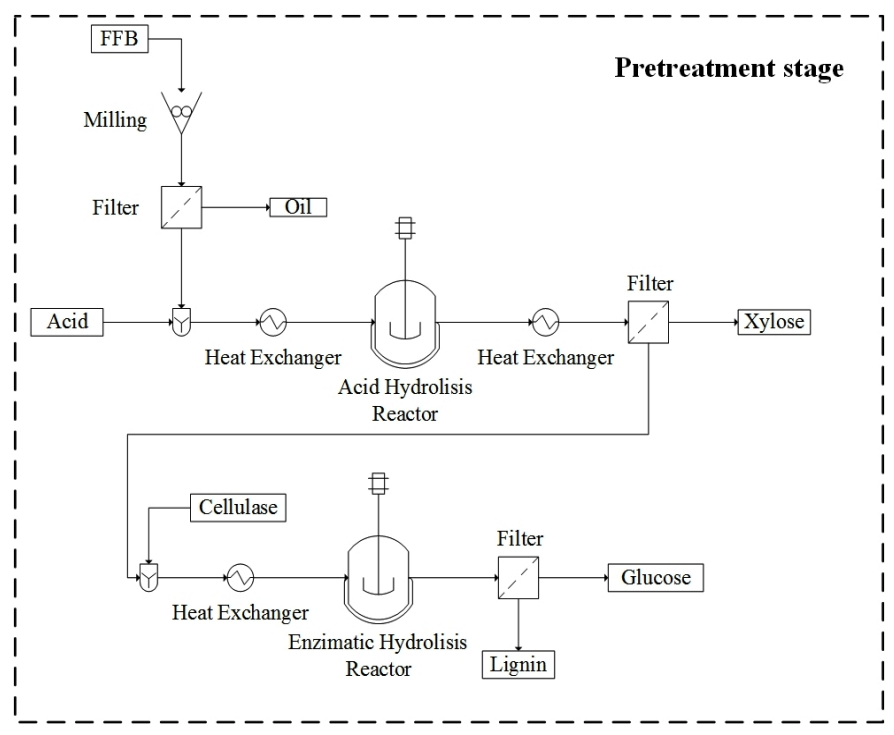

Fig.7. Flowsheet of the pretreatment process of raw material in a palm oil-based biorefinery.

ethanol, a sterilization step at $121{ }^{\circ} \mathrm{C}$ was first carried out neutralize biological activities. Then, Saccharomyces cerevisiae was employed for the ethanolic fermentation at $37{ }^{\circ} \mathrm{C}$, according to the kinetics previously reported by Rivera et al. (2006). A gravity sedimentation process was then carried out in order to separate the biomass generated during the fermentation process. After the fermentation process, the culture medium contained approximately $5-10 \%$ ethanol in concentration. The broth underwent a distillation, rectification, and a dehydration process with molecular sieves in order to increase the aforementioned ethanol concentration to as high as $99.6 \mathrm{wt. \%}$ (Pitt et al., 1983).

Figure 9 presents the process of syngas and electricity production. The final solid fraction mainly consisting of lignin was introduced into a gasification process in which synthesis gas was generated and was used in a turbine to obtain electricity. The synthesis gas was composed of mainly $\mathrm{H}_{2}, \mathrm{CO}, \mathrm{CH}_{4}$, and $\mathrm{CO}_{2}$ (Manatura et al., 2017). Figure 10 presents the process to obtain xylitol. The xylose obtained in the pretreatment step was used for the production of

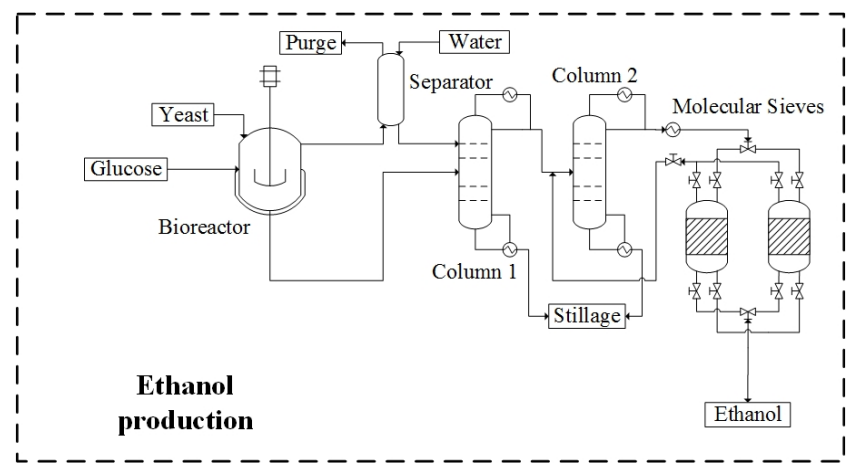

Fig.8. Flowsheet for ethanol production in a palm oil-based biorefinery.

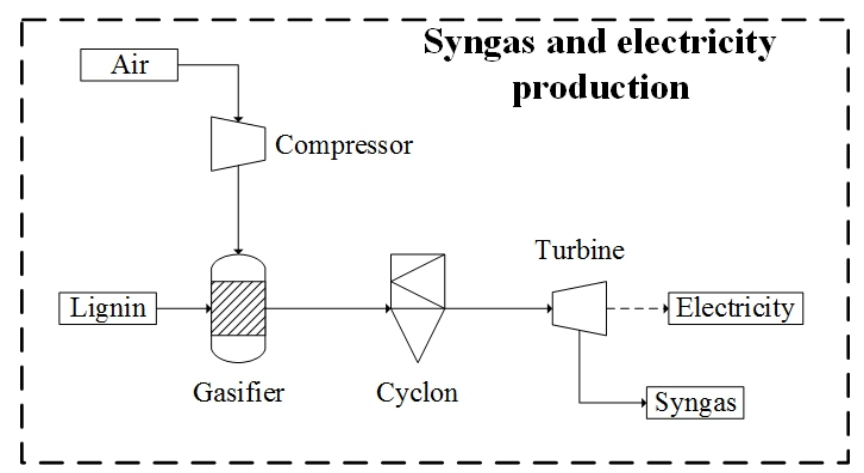

Fig.9. Flowsheet for syngas and electricity generation in a palm oil-based biorefinery.

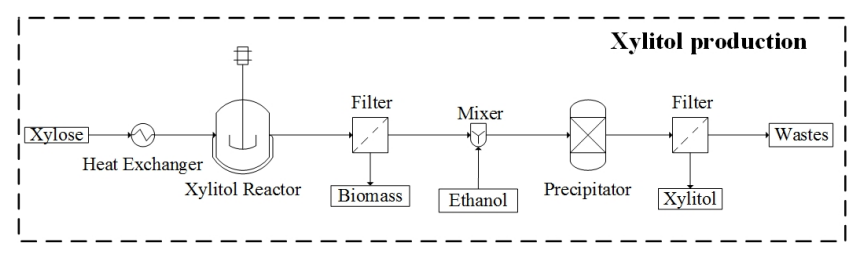

Fig.10. Flowsheet for xylitol production in a palm oil-based biorefinery.

xylitol. The fermenting microorganism employed was Candida parapsilosis at $30{ }^{\circ} \mathrm{C}$. The kinetics used for this case was those described by Aranda-Barradas et al. (2000). After the fermentation, the biomass obtained was separated by means of a filtration process. The obtained liquid fraction was then mixed with ethanol in a 1:1 ratio in order to precipitate the xylitol (Mussatto et al., 2005). Once xylitol was precipitated, it is separated by means of a filtration process. The ethanol used at stage was what previously produced.

Figure 11 shows the process for the production of biodiesel. In the first step, basic catalyst $(\mathrm{NaOH})$ was mixed with alcohol (ethanol) (Bambase et al., 2007), generated previously in the process. The resulting solution was then mixed with oil and was heated to $60{ }^{\circ} \mathrm{C}$. This solution was sent to a reactor in which the transesterification reaction was performed according to the kinetics reported by Likozar and Levec (2014). Upon the completion of the reaction, the excess ethanol was recovered using a distillation column. Subsequently, the mixture of un-reacted oil and biodiesel including 


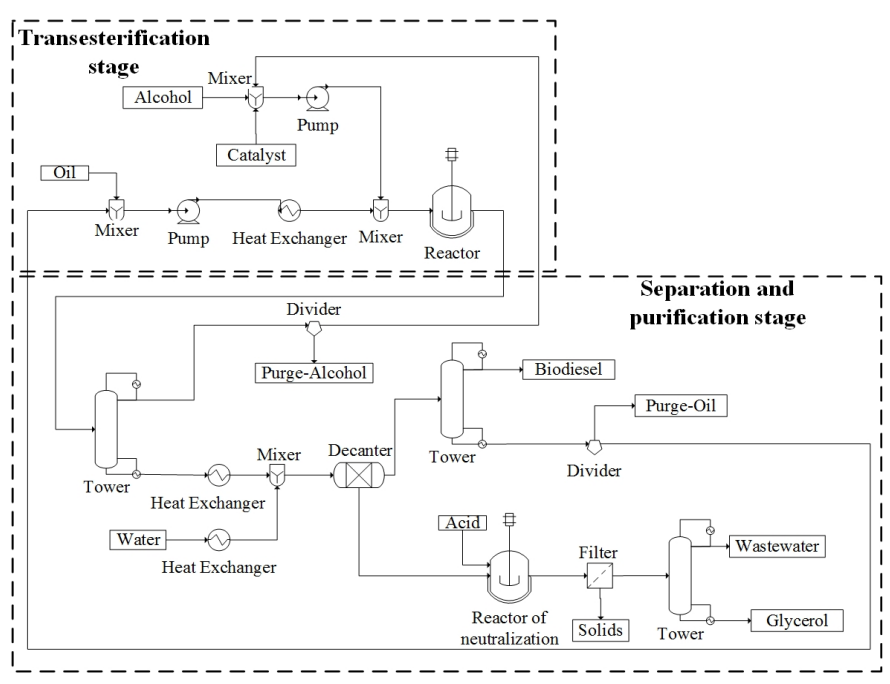

Fig.11. Flowsheet for biodiesel production from palm oil in a palm oil-based biorefinery.

glycerol was mixed with a stream of preheated water in a ratio of $1: 3 \mathrm{v} / \mathrm{v}$ and the mixture was sent to a decanter where the produced biodiesel and the unreacted oil were separated as one stream from the second stream, i.e., water and glycerol. The biodiesel and un-reacted oil stream was sent to another distillation tower where biodiesel was obtained with a purity of $95 \mathrm{wt} . \%$. The recovered oil was re-sent to the transesterification reactor. Glycerol contained in the second stream was also separated as co-product and underwent further purification reaching a purity of $80 \mathrm{wt} . \%$. Recycled water was re-used in the biodiesel water-washing process.

\subsubsection{Environmental analysis}

The environmental analysis was performed by using the Waste Reduction (WAR) algorithm, developed by the Environmental Protection Agency (EPA). This algorithm calculates the potential environmental impact (PEI) per kg of product. Eight potential environmental categories of the proposed process schemes were evaluated: Human Toxicity per Ingestion (HTPI), Human Toxicity per Exposure (HTPE), Terrestrial Toxicity Potential (TTP), Aquatic Toxicity Potential (ATP), Global Warming Potential (GWP), Ozone Depletion Potential (ODP), Photochemical Oxidation or Smog Formation Potential (PCOP), and Acidification Potential (AP) (Young et al., 2000).

In order to evaluate the environmental feasibility of the biorefinery under investigation, the following scenarios were proposed and analyzed:

1. Production of biodiesel, glycerol, xylitol, electricity, synthesis gas, and ethanol

2. Production of biodiesel, xylitol, synthesis gas, electricity, and ethanol

3. Production of biodiesel, synthesis gas, electricity, and ethanol

4. Production of biodiesel

\subsubsection{Economic analysis}

The results of the material and energy balance obtained from the Aspen Plus and the energy requirements for each equipment were used as a starting point for the economic evaluation of the biorefinery. This economic evaluation was performed using Aspen Process Economic Analyzer software. The computational tool was used to determine the costs of raw materials and inputs, process profits, general and administrative expenses, operating costs, operating and maintenance costs, taking into account all parameters in the Colombian context. In addition, depreciation was determined using the straight-line method. Information on raw material and input costs is presented in Table 7.
Table 7.

Costs of raw materials and parameters of economic analysis for a palm oil-based biorefinery in the Colombian context.

\begin{tabular}{|c|c|c|c|}
\hline Item & Unit & Value & Reference \\
\hline \multicolumn{4}{|l|}{ Inversion parameters } \\
\hline Tax rate & $\%$ & 25 & \multirow{2}{*}{ Dávila et al. (2014) } \\
\hline Interest rate & $\%$ & 17 & \\
\hline \multicolumn{4}{|l|}{ Raw materials } \\
\hline FFB & USD/tonne & 82.39 & Mosquera et al. (2016) \\
\hline Calcium hydroxide & USD/kg & 239.9 & Sigma-Aldrich (2017) \\
\hline Sulfuric acid & USD/tonne & 25 & \multirow{2}{*}{ ICIS (2017) } \\
\hline Ethanol & USD/gal & 2.11 & \\
\hline \multicolumn{4}{|l|}{ Utilities } \\
\hline Low pressure steam & USD/tonne & 1.57 & \multirow{3}{*}{ Moncada et al. (2015) } \\
\hline Medium pressure steam & USD/tonne & 8.18 & \\
\hline High pressure steam & USD/tonne & 9.86 & \\
\hline Water & $\mathrm{USD} / \mathrm{m}^{3}$ & 1.25 & \multirow{3}{*}{ Dávila et al. (2014) } \\
\hline Fuel & USD/MMBTU & 7.21 & \\
\hline Electricity & USD/kWh & 0.10 & \\
\hline \multicolumn{4}{|l|}{ Operation } \\
\hline Operator & $\mathrm{USD} / \mathrm{h}$ & 2.14 & \multirow{2}{*}{ Dávila et al. (2014) } \\
\hline Supervisor & $\mathrm{USD} / \mathrm{h}$ & 4.29 & \\
\hline
\end{tabular}

\subsection{Outcomes}

\subsubsection{Process design}

After performing the simulation of the proposed process, the following yields were obtained for the production of biodiesel, glycerol, xylitol, syngas, and ethanol: $0.24,0.046,0.40,0.54$. and $0.122 \mathrm{~kg} / \mathrm{kg}$ of raw material, respectively. In addition, $1,265.63 \mathrm{~kW}$ could be obtained. In another word, $0.126 \mathrm{~kW} / \mathrm{kg}$ of raw material would be generated

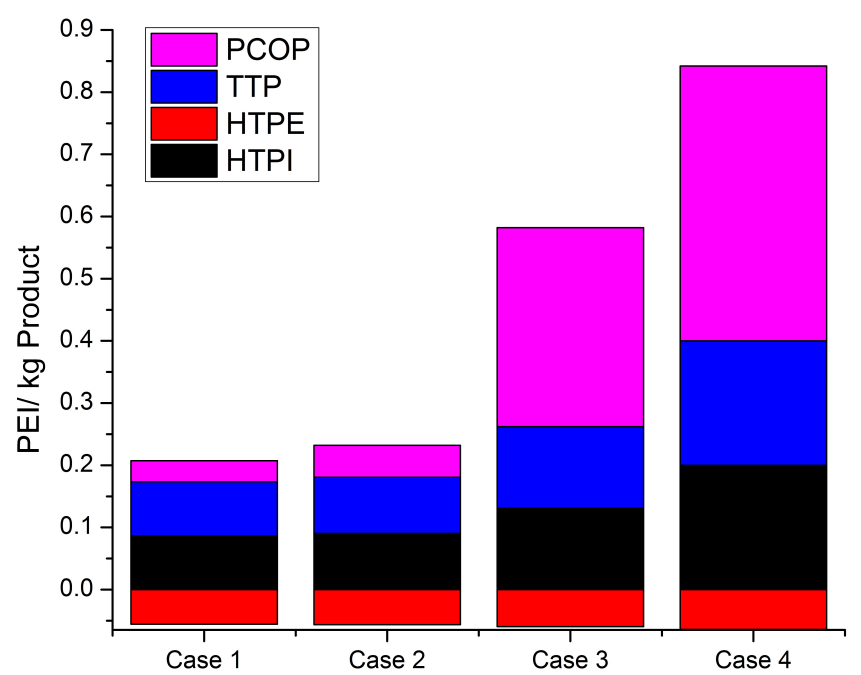

Fig.12. The results of the environmental analysis of different scenarios considered under the scheme of a palm oil-based biorefinery.

\subsubsection{Environmental analysis}

Figure 12 presents the results of the environmental analysis for each scenario. It could be clearly seen that that the environmental impacts of the 
process diminished by further using the raw material, i.e., when more valueadded products were obtained. This was due to the fact that a smaller fraction of the raw material was being discarded and instead would be used to obtain value-added products. For this reason, Scenario 1 had the lowest environmental impacts in comparison with the other scenarios. Likewise, it was possible to observe that the worst environmental impact was attributed to Scenario 4 where only biodiesel production was targeted. This was mainly due to the large amount of water required during the process and the wastewater generated contained a high organic load, thus worsening its environmental impacts.

\subsubsection{Economic analysis}

Table 8 presents the results of the economic analysis for the biorefinery based on FFB as raw material. It can be observed that the main cost was associated with the cost of the raw material used. Having analyzed the sale prices of the various products obtained in the biorefinery, it could be concluded that sole production of biodiesel on the analyzed scale would not cover all the production costs. Therefore, it would be necessary to use the raw material to obtain other products such as xylitol, ethanol, syngas, and electricity in addition to biodiesel as well. For instance, ethanol could be used for the production of the biodiesel, which would reduce the costs of ethanol used in the process. Likewise, on-site produced ethanol could also be used for the purification of xylitol. On the other hand, the electricity generated could be used to supply the energy demands of the production process incorporated in the biorefinery.

Table 8.

Economic analysis for the biorefinery based on FFB as raw material.

\begin{tabular}{ll}
\hline Item & USD/h \\
\hline Raw materials cost & $720,566.6$ \\
\hline Utilities cost & $3,297.2$ \\
\hline Operating labor cost & 6.4 \\
\hline Maintenance cost & 0.2 \\
\hline Plant overhead & 1.6 \\
General and administration cost & 3.3 \\
\hline Depreciation expense & 12.6 \\
\hline
\end{tabular}

Table 9.

Price distribution for the production of biodiesel, xylitol, syngas, glycerol, and electricity in palm oil-based biorefinery.

\begin{tabular}{lllll}
\hline Product & Share (\%) & Production cost & Sale price & Reference \\
\hline Biodiesel & 17.97 & $0.03 \mathrm{USD} / \mathrm{gal}$ & $3.64 \mathrm{USD} / \mathrm{gal}$ & Biodiesel (2017) \\
Xylitol & 29.44 & $15.66 \mathrm{USD} / \mathrm{kg}$ & $164.00 \mathrm{USD} / \mathrm{kg}$ & Sigma-Aldrich (2017) \\
Syngas & 39.88 & $16.97 \mathrm{USD} / \mathrm{m}^{3}$ & $0.62 \mathrm{USD} / \mathrm{m}^{3}$ & CETC (2017) \\
Glycerol & 3.41 & $0.002 \mathrm{USD} / \mathrm{L}$ & $53.24 \mathrm{USD} / \mathrm{L}$ & Fisher Scientific (2017) \\
Electricity & 9.30 & $4.95 \mathrm{USD} / \mathrm{kW}$ & $0.1 \mathrm{USD} / \mathrm{kW}$ & $\mathrm{EPM} \mathrm{(2017)}$
\end{tabular}

To determine the share each product contributing to the total cost of production in the biorefinery, ethanol was not considered as it was used as raw material within the same biorefinery. Table 9 shows the price distribution for the production of biodiesel, xylitol, syngas, glycerol, and electricity. Comparing these costs with the sale prices, it is possible to conclude that biodiesel, xylitol, and glycerol had a profit margin greater than $99 \%$ while the other products possessed a production cost higher than their sale prices. Such findings could be indications on how to optimize the biorefinery to further enhance profits by modifying the stages involved in biorefinery design.

\section{Conclusions}

In general, the integral use of biomass under the concept of biorefinery allows economic, environmental, and social advantages over individual processes. However, it is important to note that a biorefinery must be conceptualized beforehand in such a way that the selection of technologies, raw materials, and product will be optimal. In case of biodiesel for example as investigated herein, the use of the biorefinery concept would allow the use of both lignocellulosic and non-lignocellulosic (glycerol) wastes for the production of added-value products leading to more economic benefits for the overall process. Moreover, the integral use of the biomass in the biodiesel production process would result in reduced generation of residues and thus, a more environment friendly process. Nevertheless, a berefinery needs to be simulated and optimized accordingly in order to ensure the highest level of economic and environmental sustainability. It should also be noted that job creation and rural development are two fundamental aspects of different biorefineries including biodiesel biorefineries which should not be overlooked

\section{References}

[1] Aguilar, R., Ramırez, J.A., Garrote, G., Vázquez, M., 2002. Kinetic study of the acid hydrolysis of sugar cane bagasse. Int. J. Food Eng. 55(4), 309-318

[2] Ali, C.H., Qureshi, A.S., Mbadinga, S.M., Liu, J.F., Yang, S.Z., Mu, B.Z., 2017. Biodiesel production from waste cooking oil using onsite produced purified lipase from Pseudomonas aeruginosa FW_SH-1: central composite design approach. Renewable Energy. 109, 93-100.

[3] Aranda-Barradas, J.S., Delia, M.L., Riba, J.P., 2000. Kinetic study and modelling of the xylitol production using Candida parapsilosi in oxygen-limited culture conditions. Bioprocess. Biosyst. Eng. 22(3), 219-225

[4] Azad, A.K., Rasul, M.G., Khan, M.M.K., Sharma, S.C., Hazrat, M.A., 2015. Prospect of biofuels as an alternative transport fuel in Australia. Rene. Sust. Energy Rev. 43, 331-351.

[5] Bambase, M.E., Nakamura, N., Tanaka, J., Matsumura, M., 2007. Kinetics of hydroxide-catalyzed methanolysis of crude sunflower oil for the production of fuel-grade methyl esters. J. Chem. Technol. Biotechnol. 82(3), 273-280.

[6] Barnwal, B.K., Sharma, M.P., 2005. Prospects of biodiesel production from vegetable oils in India. Rene. Sust. Energy Rev. 9(4), 363-378.

[7] Bhattacharyya, S.C., 2011. The economics of renewable energy supply, in: Energy economics: concepts, issues, markets and governance, Springer-Verlag, London, 249-271.

[8] Biodiesel fill stations and prices. http://www.usabiodieselprices.com/station_map.php. (accessed on 17 April 2017).

[9] Canakci, M., Van Gerpen, J., 2001. A pilot plant to produce biodiese from high free fatty acid feedstocks. Am. Soc. Agric. Eng. 46(4), 945-954

[10] Cardona, C.A., Aristizábal, V., Solarte, J.C., 2016. Improvement of palm oil production for food industry through biorefinery concept, in Taylor, J.C. (Ed.), Advances in Chemistry Research. Nova Science Publishers, NY, USA, pp. 1-36.

[11] Chang, S.H., 2014. An overview of empty fruit bunch from oil palm as feedstock for bio-oil production. Biomass Bioenergy. 62, 174-181.

[12] Cherubini, F., 2010. The biorefinery concept: using biomass instead of oil for producing energy and chemicals. Energy Convers. Manage. 51(7), 1412-1421.

[13] Cherubini, F., Ulgiati, S., 2010. Crop residues as raw materials for biorefinery systems - an LCA case study. Appl. Energy. 87(1), 47-57.

[14] Chew, K.W., Yap, J.Y., Show, P.L., Suan, N.H., Juan, J.C., Ling, T.C., Lee, D.J., Chang, J.S., 2017. Microalgae biorefinery: high value products perspectives. Bioresour. Technol. 229, 53-62.

[15] Chisti, Y., 2013. Constraints to commercialization of algal fuels. J Biotechnol. 167(3), 201-214.

[16] Christenson, D.P., Goldfarb, J.L., Kriner, D.L., 2017. Costs, benefits, and the malleability of public support for "Fracking". Energy Policy. 105, 407-417.

[17] Dávila, J.A., Hernández, V., Castro, E., Cardona, C.A., 2014 Economic and environmental assessment of syrup production. Colombian case. Bioresour. Technol. 161, 84-90.

[18] Daza, L.V., Solarte, J.C., Serna, S., Chacón, Y., Cardona, C.A., 2016. Agricultural waste management through energy producing 
biorefineries: The Colombian case. Waste Biomass Valorization. 7(4), 789-798.

[19] Dias, J.M., Alvim-Ferraz, M.C., Almeida, M.F., 2008. Mixtures of vegetable oils and animal fat for biodiesel production: influence on product composition and quality. Energy Fuels. 22(6), 3889-3893.

[20] EPM |Empresa de servicios públicos de Colombia (accessed on 17 April 2017).

[21] Fassinou, W.F., 2012. Higher heating value (HHV) of vegetable oils, fats and biodiesels evaluation based on their pure fatty acids' HHV. Energy. 45(1), 798-805.

[22] Feyzi, M., Hosseini, N., Yaghobi, N., Ezzati, R., 2017. Preparation, characterization, kinetic and thermodynamic studies of $\mathrm{MgO}-\mathrm{La}_{2} \mathrm{O}_{3}$ nanocatalysts for biodiesel production from sunflower oil. Chem. Phys. Lett. 677, 19-29.

[23] Fisher scientific: lab equipment and supplies (accessed on 17 April 2017).

[24] Ghatak, H.R., 2011. Biorefineries from the perspective of sustainability: feedstocks, products, and processes. Renew. Sust. Energy Rev. 15(8), 4042-4052.

[25] González-Delgado, Á.D., Kafarov, V., 2011. Microalgae based biorefinery: issues to consider. CT\&F-Ciencia, Tecnología y Futuro. 4(4), 5-22.

[26] Gutiérrez, L.F., Sánchez, Ó.J., Cardona, C.A., 2009. Process integration possibilities for biodiesel production from palm oil using ethanol obtained from lignocellulosic residues of oil palm industry. Bioresour. Technol. 100(3), 1227-1237

[27] Helwani, Z., Othman, M.R., Aziz, N., Fernando, W.J.N., Kim, J., 2009. Technologies for production of biodiesel focusing on green catalytic techniques: a review. Fuel Process. Technol. 90(12), 1502-1514.

[28] Huang, G., Chen, F., Wei, D., Zhang, X., Chen, G., 2010. Biodiesel production by microalgal biotechnology. Appl. Energy. 87(1), 38-46.

[29] ICIS. (accessed on 13 April 2017).

[30] IndexMundi Statistics (accessed on 15 April 2017).

[31] Leung, D.Y., Wu, X., Leung, M.K.H., 2010. A review on biodiesel production using catalyzed transesterification. Appl. Energy. 87(4), 1083-1095.

[32] Likozar, B., Levec, J., 2014. Transesterification of canola, palm, peanut, soybean and sunflower oil with methanol, ethanol, isopropanol, butanol and tert-butanol to biodiesel: Modelling of chemical equilibrium, reaction kinetics and mass transfer based on fatty acid composition. Appl. Energy 123:108-120.

[33] Long, N.V.D., Kim, S., Lee, M., 2016. Design and optimization of intensified biorefinery process for furfural production through a systematic procedure. Biochem. Eng. J. 116, 166-175.

[34] Lü, J., Sheahan, C., Fu, P., 2011. Metabolic engineering of algae for fourth generation biofuels production. Energy Environ. Sci. 4(7), 24512466

[35] Manatura, K., Lu, J.H., Wu, K.T., Hsu, H.T., 2017. Exergy analysis on torrefied rice husk pellet in fluidized bed gasification. Appl. Therm. Eng. 111, 1016-1024.

[36] Mansoornejad, B., Chambost, V., Stuart, P., 2010. Integrating product portfolio design and supply chain design for the forest biorefinery. Chem. Phys. Lett. 34(9), 1497-1506.

[37] Marchetti, J.M., Miguel, V.U., Errazu, A.F., 2007. Possible methods for biodiesel production. Renew. Sust. Energy Rev. 11(6), 1300-1311.

[38] Martinez-Hernandez, E., Sadhukhan, J., Campbell, G.M., 2013. Integration of bioethanol as an in-process material in biorefineries using mass pinch analysis. Appl. Energy. 104, 517-526.

[39] Mata, T.M., Martins, A.A., Caetano, N.S., 2010. Microalgae for biodiesel production and other applications: A review. Renew. Sust. Energy Rev. 14(1), 217-232

[40] Math, M.C., Kumar, S.P., Chetty, S.V., 2010. Technologies for biodiesel production from used cooking oil - A review. Energy Sustainable Dev. 14(4), 339-345

[41] Mathioudakis, V., Gerbens-Leenes, P.W., Van der Meer, T.H., Hoekstra, A.Y., 2017. The water footprint of second-generation bioenergy: A comparison of biomass feedstocks and conversion techniques. J. Cleaner Prod. 148, 571-582.

[42] Meher, L.C., Sagar, D.V., Naik, S.N., 2006. Technical aspects of biodiesel production by transesterification - a review. Renew. Sust. Energy Rev. 10(3), 248-268
[43] Moncada, J., Aristizábal, V., Cardona, C.A., 2016. Design strategies for sustainable biorefineries. Biochem. Eng. J. 116, 122-134.

[44] Moncada, J., El-Halwagi, M.M., Cardona, C.A., 2013. Technoeconomic analysis for a sugarcane biorefinery: Colombian case. Bioresour. Technol. 135, 533-543.

[45] Moncada, J., Hernández, V., Chacón, Y., Betancourt, R., Cardona, C. A., 2015. Citrus based biorefineries. in: Simmons, D., (Eds.) Citrus fruits. production, consumption and health benefits, Nova Publishers, pp. 1-26.

[46] Moncada, J., Tamayo, J.A., Cardona, C.A., 2014. Integrating first, second, and third generation biorefineries: Incorporating microalgae into the sugarcane biorefinery. Chem. Eng. Sci. 118, 126-140.

[47] Mosquera, M., Valderrama, M., Fontanilla, C., Ruíz, E., Uñate, M., Rincón, F., Arias, N. 2016. Costos de producción de la agroindustria de la palma de aceite en Colombia en 2014. Palmas. 37(2), 37-53.

[48] Montoya, M.R., Cardona, C.A., Orrego, C., Gutiérrez, L., 2006. Obtención de biodiesel por reacción extractiva. Rev. Energía y Comput. 14(2), 49-57.

[49] Mussatto, S.I., Santos, J.C., Filho, W.C., Silva, S.S., 2005 Purification of xylitol from fermented hemicellulosic hydrolyzate using liquid-liquid extraction and precipitation techniques. Biotechnol. Lett. 27(15), 1113-1115.

[50] Naik, S.N., Goud, V.V., Rout, P.K., Dalai, A.K., 2010. Production of first and second generation biofuels: a comprehensive review. Renew. Sust. Energy Rev. 14(2), 578-597.

[51] Nasdaq. globenewswire. hongli clean energy technologies corp. reports fiscal year 2016 q2 financial results Nasdaq: CETC https://globenewswire.com/ (accessed on 17 April 2017).

[52] Negm, N.A., Sayed, G.H., Yehia, F.Z., Habib, O.I., Mohamed, E.A. 2017. Biodiesel production from one-step heterogeneous catalyzed process of Castor oil and Jatropha oil using novel sulphonated phenyl silane montmorillonite catalyst. J. Mol. Liq. 234, 157-163.

[53] O'Keeffe, S., Schulte, R.P.O., Sanders, J.P.M., Struik, P.C., 2012. II Economic assessment for first generation green biorefinery (GBR) scenarios for an Irish GBR blueprint. Biomass Bioenergy. 41, 1-13.

[54] Patel, R.L., Sankhavara, C.D., 2017. Biodiesel production from Karanja oil and its use in diesel engine: a review. Renew. Sust. Energy Rev. 71, 464-474.

[55] Philippidis, G.P., Smith, T.K., Wyman, C.E., 1993. Study of the enzymatic hydrolysis of cellulose for production of fuel ethanol by the simultaneous saccharification and fermentation process. Biotechnol. Bioeng. 41(9), 846-853.

[56] Pitt, W.W., Haag, G.L., Lee, D.D., 1983. Recovery of ethanol from fermentation broths using selective sorption-desorption. Biotechnol. Bioeng. 25(1), 123-131.

[57] Posada, J.A., Rincón, L.E., Cardona, C.A., 2012. Design and analysis of biorefineries based on raw glycerol: addressing the glycerol problem. Bioresour. Technol. 111, 282-293.

[58] Prasertsan, S., Prasertsan, P., 1996. Biomass residues from palm oil mills in Thailand: an overview on quantity and potentia usage. Biomass Bioenergy. 11(5), 387-395.

[59] Proyección de demanda combustibles líquidos en Colombia, Unidad Planeación Min. Energética, UPME, 2016.

[60] Quintero, J.A., Felix, E.R., Rincón, L.E., Crisspín, M., Baca, J.F. Khwaja, Y., Cardona, C.A., 2012. Social and techno-economical analysis of biodiesel production in Peru. Energy Policy. 43, 427-435.

[61] Rincón, L.E., Jaramillo, J.J., Cardona, C.A., 2014. Comparison of feedstocks and technologies for biodiesel production: An environmental and techno-economic evaluation. Renewable Energy. 69, 479-487.

[62] Rincón, L.E., Moncada, J., Cardona, C.A., 2014. Analysis of potential technological schemes for the development of oil palm industry in Colombia: a biorefinery point of view. Ind. Crops Prod. 52, 457-465.

[63] Rivera, E.C., Costa, A.C., Atala, D.I., Maugeri, F., Maciel, M.R.W., Filho, R.M., 2006. Evaluation of optimization techniques for parameter estimation: application to ethanol fermentation considering the effect of temperature. Process Biochem. 41(7), 1682-1687. 
[64] Sacramento-Rivero, J.C., Romero, G., Cortes-Rodriguez, E., Pech, E., Blanco-Rosete, S., 2010. A diagnostic study on the development of biorefineries in Mexico. Rev. Mex. Ing. Quím. 9(3), 261-283.

[65] Santacesaria, E., Vicente, G.M., Di Serio, M., Tesser, R., 2012. Main technologies in biodiesel production: State of the art and future challenges. Catal. Today. 195(1), 2-13.

[66] Sarkar, J., Bhattacharyya, S., 2012. Operating characteristics of transcritical $\mathrm{CO}_{2}$ heat pump for simultaneous water cooling and heating. Archives Thermodyn. 33(4), 23-40.

[67] Sigma-aldrich. https://www.sigmaaldrich.com/us-export.html. (accessed on 13 April 2017)

[68] Specification for Biodiesel (B100) - ASTM D6751, 2007.

[69] Thanh, L.T., Okitsu, K., Boi, L.V., Maeda, Y., 2012. Catalytic technologies for biodiesel fuel production and utilization of glycerol: A review. Catal. 2, 191-222.

[70] Trivedi, J., Aila, M., Bangwal, D.P., Kaul, S., Garg, M.O., 2015. Algae based biorefinery-How to make sense?. Renew. Sust. Energy Rev. 47, 295-307.
[71] Woldeyohannes, A.D., Woldemichael, D.E., Baheta, A.T., 2016. Sustainable renewable energy resources utilization in rural areas. Renew. Sust. Energy Rev. 66, 1-9.

[72] Xie, X., Shao, S., Lin, B., 2016. Exploring the driving forces and mitigation pathways of $\mathrm{CO}_{2}$ emissions in China's petroleum refining and coking industry: 1995-2031. Appl. Energy. 184, 1004-1015.

[73] Young, D., Scharp, R., Cabezas, H., 2000. The waste reduction (WAR) algorithm: environmental impacts, energy consumption, and engineering economics. Waste Manage. 20(8), 605-615.

[74] Yunos, N.S.H.M., Baharuddin, A.S., Yunos, K.F.M., Hafid, H.S. Busu, Z., Mokhtar, M.N., Sulaiman, A., Som, A.M., 2014. The physicochemical characteristics of residual oil and fibers from oil palm empty fruit bunches. Bioresour. 10(1), 14-29.

[75] Zondervan, E., Nawaz, M., de Haan, A.B., Woodley, J.M., Gani, R. 2011. Optimal design of a multi-product biorefinery system. Comput. Chem. Eng. 35(9), 1752-1766. 